\title{
Intracerebroventricular Application of Dexmedetomidine Produces Antinociception and Does not Cause Neurotoxicity in Rats
}

\author{
Ersin Köksal', Deniz Karakaya', Bilge Can ${ }^{2}$, Ayhan Bozkurt ${ }^{3}$, Sibel Barış ${ }^{1}$, Süleyman Sırrı Bilge ${ }^{4}$, Yasemin Burcu Üstün \\ ${ }^{1}$ Department of Anesthesiology and Reanimation, Ondokuz Mayıs University Faculty of Medicine, Samsun, Turkey \\ 2Department of Pathology, Ondokuz Mayıs University Faculty of Medicine, Samsun, Turkey \\ ${ }^{3}$ Department of Physiology, Ondokuz Mayıs University Faculty of Medicine, Samsun, Turkey \\ ${ }^{4}$ Department of Pharmacology, Ondokuz Mayıs University Faculty of Medicine, Samsun, Turkey
}

\begin{abstract}
Background: Alpha ${ }_{2}$ agonists contribute to pain control at the level of the medulla spinalis. Alpha ${ }_{2}$ agonists are generally added to local anaesthetics to prolong spinal or epidural anaesthesia time.

Aims: In the present study, we aimed to evaluate the antinociceptive and neurotoxic effects of dexmedetomidine given intracerebroventricularly for 5 days.

Study Design: Animal experimentation.

Methods: After intraventricular cannulation, rats $(n=32)$ were divided into two groups ( $n=16$ each). Rats in the dexmedetomidine group (Group $D$, $n=16$ ) received $3 \mu \mathrm{g}(0.03 \mathrm{~mL}$ ) dexmedetomidine and the control group (Group $\mathrm{C}, \mathrm{n}=16)$ received $0.03 \mathrm{~mL}$ physiological serum through an intracerebroventricular catheter once a day, for 5 days. Antinociceptive, sedative, and motor effects were evaluated before the injection and for 90 min after injection. The tail-flick and hot plate tests were used to assess thermal nociceptive threshold. For histopathological evaluation, half of the rats in both groups were sacrificed on the $6^{\text {th }}$ day and the remaining rats were sacrificed on the $21^{\text {st }}$ day. Then the perfusion fixation method was applied. The first tissue section was obtained from the cervical spinal cord $1 \mathrm{~cm}$ distal to the proximal end of the spinal cord. The second sample was retrieved from the region $1 \mathrm{~cm}$ distal from the thoracic 13-lumbar 1 vertebra. On morphological evaluation, nonspecific changes like edema and gliosis, signs of neuronal degeneration demonstrating a severe reaction, and density of inflammatory cells were examined.

Results: In dexmedetomidine-administered rats, on the first day reaction times at 5, 10, and $20 \mathrm{~min}$ and on the other days, reaction times at 5, 10, 20, and $30 \mathrm{~min}$ in hot plate tests were significantly longer compared with baseline values $(\mathrm{p}<0.05)$. In dexmedetomidine-administered rats, on the $1^{\text {st }}, 4^{\text {th }}$, and $5^{\text {th }}$ days reaction times at $5,10,20,30$, and 40 min and on the $2^{\text {nd }}$ and $3^{\text {rd }}$ days reaction times at $5,10,20$, and 30 min in tail-flick tests were significantly longer compared with baseline values $(p<0.05)$. First-degree sedation lasting for $60 \mathrm{~min}$ and first-degree motor block lasting for 30-40 min were observed in the dexmedetomidine group. Similar rates of nonspecific changes such as edema and gliosis were seen in both groups. Signs of severe reactions such as neuronal degeneration and diffuse inflammatory cell infiltration were not encountered in any group. There was no significant difference between groups according to morphological findings of the spinal cord on the $6^{\text {th }}$ and $21^{\text {st }}$ days $(p>0.05)$.
\end{abstract}

Conclusion: We observed that intracerebroventricular administration of $3 \mu \mathrm{g}$ dexmedetomidine produced antinociception and did not cause neurotoxicity.

Key Words: Dexmedetomidine, analgesia, neurotoxicity

Received: 19.09.2012

Accepted: 31.07.2013

\section{Introduction}

Alpha $_{2}$ agonists contribute to pain control at the level of the medulla spinalis via descendant neuroadrenergic systems originating from the brain. Neuroadrenergic neurons stemming from the locus coeruleus and subcoeruleus nuclei send projections to the posterior horn of the medulla spinalis. Stimulation of this pathway provides antinociception, apparently dependent on noradrenaline discharge (1). Alpha ${ }_{2}$ agonists are frequently added to local anaesthetic agents in order to prolong the duration of spinal or epidural anesthesia. An alpha ${ }_{2}$ agonist drug, clonidine, extends the duration of analgesia in patients receiving spinal or epidural anaesthesia when given in combination with local anaesthetics, opioids, or both $(2,3)$. In studies performed on rats, sedative effects of alpha $_{2}$ agonists were suggestively related to the alpha $a_{2 A}$ subtype, which involved the region of the locus coeruleus $(4,5)$.
Compared with other alpha ${ }_{2}$ agonists, dexmedetomidine has a higher affinity for receptors, and its spinal antinociceptive efficacy has been demonstrated in animal studies $(6,7)$. It was reported that long-term intrathecal drug application could induce permanent neuronal damage especially following spinal anaesthesia $(8,9)$. However, the neurotoxic effects of intrathecal or intracerebroventricular dexmedetomidine application are not known.

In this study, we applied dexmedetomidine via the intracerebroventricular route for 5 days using a different catheterisation technique, with the intention to investigate its antinociceptive, sedative, and neurotoxic effects on the spinal cord.

\section{Material and Methods}

This study was performed on 32 16-week-old Wistar strain male rats weighing 250-300 $\mathrm{g}$ after obtaining the approval of 
the Ethics Committee of Medical and Surgical Research Center, Ondokuz Mayıs University Faculty of Medicine. During the study period, all rats had access to water and food ad lib and were kept in cages exposed to alternate 12 hours of dark and light under $21 \pm 2^{\circ} \mathrm{C}$ room temperature. All rats were fasted overnight before the procedure. On the day of the experiment, the rats that were given ketamine (Ketalar, Pfizer, Istanbul, Turkey) anaesthesia (100 mg/kg) via the intraperitoneal (i.p.) route were fixed on a stereotactic surgical apparatus (Stoelting Inc., IL, USA). Then, as described by Paxinos and Watson (10), a burr hole was opened $1.1 \mathrm{~mm}$ posterior and $1.5 \mathrm{~mm}$ lateral to the bregma, and a stainless steel catheter was inserted into the cranium and advanced deeply for $3.5 \mathrm{~mm}$. After observing the outflow of cerebrospinal fluid from the catheter lumen, it was fixed and immobilised with dental acrylic resin and its external end was closed with a plastic plug. For prophylaxis, all rats were given $30 \mathrm{mg} / \mathrm{kg}$ ampicillin i.p.

\section{Experimental design}

The rats were randomly allocated into two groups 3 days after catheterisation. Rats in the dexmedetomidine group (Group D, $\mathrm{n}=16)$ received $3 \mu \mathrm{g}(0.03 \mathrm{~mL})$ dexmedetomidine (Precedex; Hospira, $100 \mu \mathrm{g} / \mathrm{mL}$ ); the control group (Group $C, n=16$ ) received $0.03 \mathrm{~mL}$ physiological serum through an intracerebroventricular catheter once a day, for 5 days. Rats displaying abnormal posture, motor deficit, infection, and impaired health state were excluded from the study.

Nociceptive, motor function, and sedation assessment tests were applied for 5 days between 9 AM and 5 PM, before and $5,10,20,30,40,60$, and 90 min after injections in a random fashion every day. Pre-injection values were recorded as baseline, and post-injection values were recorded as test variables.

\section{Nociceptive evaluation}

Thermal stimulation models were used.

Hot plate test (supraspinal pain test): The test was performed according to the method described by Eddy and Leimbach (11). Reaction times of the rats placed on a hot metal plate apparatus with a thermostat that kept the temperature of the plate at $55 \pm 0.5^{\circ} \mathrm{C}$ (Ugo Basile, Thermal Plantar ${ }^{\mathrm{TM}}$, Verase, Italy) were recorded. Jumping, licking, or withdrawing of the hind paws were accepted as a positive reaction. The time interval between placing the rat on the hot plate and the first sign of a positive reaction was also recorded. To prevent tissue damage, rats were left on the hot plate for 60 seconds at most.

Tail-flick test (spinal pain test): The test was performed according to the method described by D'Amour and Smith (12). The tail of the rat was half dipped in a water tank with a stable temperature of $55 \pm 0.5^{\circ} \mathrm{C}$. Tail flick or an audible reaction was accepted as a positive reaction, and the time interval between immersion of the tail and the first sign of a positive reaction was recorded. To prevent tissue damage, the duration of the tail-flick test was limited to 15 seconds.

Latencies (reaction times) measured during hot plate and tail-flick tests were compared with baseline values to calculate the percentage of maximum possible effect (MPE):
$\operatorname{MPE}(\%)=100 \times[$ (test value - baseline value) $/$ (cut-off time - baseline value)]

Sedation level: Based on the severity of reactions induced by vocal and tactile stimuli, the degree of sedation was evaluated between 0 and 2 ( 0 =active, $1=$ tendency to sleep, response to stimuli; $2=$ sleepy, no response to stimuli) (13).

Motor function: Stepping and righting reflexes were evaluated using the Yamamoto scoring system (14). The responses obtained during these tests ranged between 0 and $2(0=$ no motor response; $1=$ slower than normal motor response; 2 =normal motor response).

\section{Histopathological evaluation}

Half of the rats in both groups (eight rats from each group) were sacrificed on the $6^{\text {th }}$ day and the remaining rats (eight rats from each group) were sacrificed on the $21^{\text {st }}$ day after intracerebroventricular injection, and then the perfusion fixation method was applied with $10 \%$ formaldehyde. For histopathological evaluation, laminectomies were performed to extract the medulla spinalis of the rats. The first tissue section was obtained from the cervical spinal cord $1 \mathrm{~cm}$ distal to the proximal end of the spinal cord. The second sample was retrieved from the region $1 \mathrm{~cm}$ distal from the thoracic 13-lumbar 1 vertebra, corresponding to the last rib of the rat. All tissue samples were embedded in paraffin blocks. From each paraffin block, four pieces of $8-\mu \mathrm{m}$ thick sections were obtained, stained with haematoxylin-eosin, and evaluated under a light microscope by a pathologist blinded to the study design.

On morphological evaluation, nonspecific changes like edema and gliosis, signs of neuronal degeneration demonstrating a severe reaction, and density of inflammatory cells were examined. Using a scoring system described by Koizumi et al. (15), each histomorphological parameter was scored numerically as 0,1 , and 2 points, and the degree of destructive changes was interpreted based on the total score. Total scores were recorded as nonspecific (0-3 points), mild (4-6 points), and markedly severe (7-10 points) changes.

\section{Statistical analysis}

Data were transferred into the SPSS 13.0 software package. Wilcoxon test was used for comparison of repeated measures during hot plate and tail-flick tests, and Mann-Whitney $U$ test was used for intergroup comparison of MPE values. For qualitative data of histopathological evaluations, Fisher's exact test was applied. Data are expressed as median (minmax) and percentages. $p<0.05$ was considered statistically significant.

\section{Results}

Two rats were excluded from the study on the second day of experiments because of deterioration in general health state such as lassitude and rejection of being fed. In dexmedetomidine-administered rats, reaction times at 5, 10, and 20 min on the first day and reaction times at 5, 10, 20, and $30 \mathrm{~min}$ on the other days in hot plate tests were significantly longer compared with baseline values $(p<0.05)$ (Table 1$)$. In addition, 
reaction times at $90 \mathrm{~min}$ on the first day, at $60 \mathrm{~min}$ on the second day, at 40,60, and $90 \mathrm{~min}$ on the third day, and at $90 \mathrm{~min}$ on the fifth day in hot plate tests were significantly shorter compared with baseline values $(p<0.05)$ (Table 1).

In dexmedetomidine-administered rats, reaction times at $5,10,20,30$, and $40 \mathrm{~min}$ on the first, fourth, and fifth days and reaction times at $5,10,20$, and 30 min on the second and third days in tail-flick tests were significantly longer compared with baseline values $(p<0.05)$ (Table 2).
The percentage of MPE in hot plate and tail-flick tests were significantly longer at all times in dexmedetomidineadministered rats compared with the control group $(p<0.05)$. First-degree sedation lasting for $60 \mathrm{~min}$ was observed in all rats in the dexmedetomidine group. Sedation was not observed in the control group. First-degree block lasting for 30-40 min in stepping and righting reflexes were observed in all rats in the dexmedetomidine group. No reflex loss was observed in any rat in the control group.

Table 1. Hot plate test reaction times (in sec) for 5 days in dexmedetomidine-administered rats

\begin{tabular}{|c|c|c|c|c|c|c|c|c|c|c|c|c|c|c|c|}
\hline \multirow[b]{2}{*}{ Day } & \multirow{2}{*}{$\begin{array}{c}\text { Baseline } \\
\text { median } \\
\text { (min- } \\
\text { max) }\end{array}$} & \multicolumn{2}{|c|}{$5 \mathrm{~min}$} & \multicolumn{2}{|c|}{$10 \mathrm{~min}$} & \multicolumn{2}{|c|}{$20 \mathrm{~min}$} & \multicolumn{2}{|c|}{$30 \mathrm{~min}$} & \multicolumn{2}{|c|}{$40 \mathrm{~min}$} & \multicolumn{2}{|c|}{$60 \mathrm{~min}$} & \multicolumn{2}{|c|}{$90 \mathrm{~min}$} \\
\hline & & $\begin{array}{l}\text { median } \\
\text { (min- } \\
\text { max) }\end{array}$ & $\mathbf{p}$ & $\begin{array}{c}\text { median } \\
\text { (min- } \\
\text { max) }\end{array}$ & $\mathbf{p}$ & $\begin{array}{c}\text { median } \\
\text { (min- } \\
\text { max) }\end{array}$ & $\mathbf{p}$ & $\begin{array}{c}\text { median } \\
\text { (min- } \\
\text { max) }\end{array}$ & $\mathbf{p}$ & $\begin{array}{c}\text { median } \\
\text { (min } \\
\text { max) }\end{array}$ & $\mathbf{p}$ & $\begin{array}{c}\text { median } \\
\text { (min- } \\
\text { max) }\end{array}$ & p & $\begin{array}{c}\text { median } \\
\text { (min- } \\
\text { max) }\end{array}$ & $\mathbf{p}$ \\
\hline 1 & $\begin{array}{c}7.45 \\
(6.25- \\
8.60)\end{array}$ & $\begin{array}{l}14.00 \\
(6.00- \\
16.40)\end{array}$ & 0.017 & $\begin{array}{l}13.95 \\
(9.90- \\
20.00)\end{array}$ & 0.012 & $\begin{array}{r}12.90 \\
(10.70- \\
14.50)\end{array}$ & 0.012 & $\begin{array}{l}8.95 \\
(5.10- \\
11.50)\end{array}$ & 0.141 & $\begin{array}{c}7.00 \\
(5.00- \\
9.70)\end{array}$ & 0.324 & $\begin{array}{l}6.80 \\
(5.20 \\
7.90)\end{array}$ & 0.107 & $\begin{array}{r}6.65 \\
(5.00- \\
7.80)\end{array}$ & 0.035 \\
\hline 2 & $\begin{array}{c}8.87 \\
(6.00- \\
10.20)\end{array}$ & $\begin{array}{r}16.45 \\
(11.00- \\
20.70)\end{array}$ & 0.012 & $\begin{array}{r}16.50 \\
(14.10- \\
20.20)\end{array}$ & 0.012 & $\begin{array}{r}15.80 \\
(13.60- \\
19.80)\end{array}$ & 0.012 & $\begin{array}{r}9.30 \\
(7.80- \\
14.00)\end{array}$ & 0.030 & $\begin{array}{l}8.10 \\
(6.00- \\
13.10)\end{array}$ & 0.553 & $\begin{array}{r}8.15 \\
(6.30- \\
9.00)\end{array}$ & 0.025 & $\begin{array}{r}8.25 \\
(6.70- \\
9.80)\end{array}$ & 0.123 \\
\hline 3 & $\begin{array}{c}7.22 \\
(6.30- \\
8.40)\end{array}$ & $\begin{array}{r}15.50 \\
(13.20- \\
22.00)\end{array}$ & 0.012 & $\begin{array}{r}15.55 \\
(13.00- \\
20.00)\end{array}$ & 0.012 & $\begin{array}{r}14.70 \\
(12.50- \\
17.00)\end{array}$ & 0.012 & $\begin{array}{l}8.50 \\
(6.80- \\
11.00)\end{array}$ & 0.017 & $\begin{array}{r}6.95 \\
(6.00- \\
8.30)\end{array}$ & 0.017 & $\begin{array}{c}7.15 \\
(6.20- \\
7.90)\end{array}$ & 0.046 & $\begin{array}{r}6.85 \\
(6.00- \\
7.00)\end{array}$ & 0.036 \\
\hline 4 & $\begin{array}{c}7.77 \\
(7.00- \\
8.25)\end{array}$ & $\begin{array}{r}18.05 \\
(16.60- \\
24.00)\end{array}$ & 0.012 & $\begin{array}{r}16.95 \\
(14.80- \\
22.00)\end{array}$ & 0.012 & $\begin{array}{c}15.90 \\
(14.90- \\
19.90)\end{array}$ & 0.012 & $\begin{array}{l}11.35 \\
(9.30- \\
13.00)\end{array}$ & 0.012 & $\begin{array}{r}7.75 \\
(7.20- \\
9.10)\end{array}$ & 0.327 & $\begin{array}{r}7.70 \\
(7.00- \\
9.00)\end{array}$ & 0.575 & $\begin{array}{r}7.45 \\
(6.90- \\
8.00)\end{array}$ & 0.205 \\
\hline 5 & $\begin{array}{c}7.90 \\
(6.25- \\
8.10)\end{array}$ & $\begin{array}{r}17.75 \\
(16.00- \\
21.00)\end{array}$ & 0.012 & $\begin{array}{r}17.35 \\
(15.30- \\
24.00)\end{array}$ & 0.012 & $\begin{array}{r}16.75 \\
(15.00- \\
18.50)\end{array}$ & 0.012 & $\begin{array}{c}11.10 \\
(10.00- \\
12.00)\end{array}$ & 0.012 & $\begin{array}{l}7.90 \\
(7.00- \\
8.70)\end{array}$ & 0.233 & $\begin{array}{c}7.85 \\
(6.50- \\
8.30)\end{array}$ & 0.497 & $\begin{array}{r}7.45 \\
(6.10- \\
8.00)\end{array}$ & 0.011 \\
\hline
\end{tabular}

Table 2. Tail-flick test reaction times (in sec) for 5 days in dexmedetomidine-administered rats

\begin{tabular}{|c|c|c|c|c|c|c|c|c|c|c|c|c|c|c|c|}
\hline \multirow[b]{2}{*}{ Day } & \multirow{2}{*}{$\begin{array}{c}\text { Baseline } \\
\begin{array}{c}\text { median } \\
\text { max }\end{array}\end{array}$} & \multicolumn{2}{|c|}{$5 \mathrm{~min}$} & \multicolumn{2}{|c|}{$10 \mathrm{~min}$} & \multicolumn{2}{|c|}{$20 \mathrm{~min}$} & \multicolumn{2}{|c|}{$30 \mathrm{~min}$} & \multicolumn{2}{|c|}{$40 \mathrm{~min}$} & \multicolumn{2}{|c|}{$60 \mathrm{~min}$} & \multicolumn{2}{|c|}{$90 \mathrm{~min}$} \\
\hline & & $\begin{array}{c}\text { median } \\
\text { (min- } \\
\text { max) }\end{array}$ & $\mathbf{p}$ & $\begin{array}{c}\text { median } \\
\text { (min- } \\
\text { max) }\end{array}$ & $\mathbf{p}$ & $\begin{array}{c}\text { median } \\
\text { (min- } \\
\text { max) }\end{array}$ & p & $\begin{array}{c}\text { median } \\
\text { (min- } \\
\text { max) }\end{array}$ & $\mathbf{p}$ & $\begin{array}{c}\text { median } \\
\text { (min } \\
\text { max) }\end{array}$ & $\mathbf{p}$ & $\begin{array}{c}\text { median } \\
\text { (min- } \\
\text { max) }\end{array}$ & p & $\begin{array}{c}\text { median } \\
\text { (min- } \\
\text { max) }\end{array}$ & $\mathbf{p}$ \\
\hline 1 & $\begin{array}{c}5.22 \\
(4.40- \\
5.50)\end{array}$ & $\begin{array}{l}9.20 \\
(8.30- \\
10.50)\end{array}$ & 0.012 & $\begin{array}{c}9.85 \\
(7.90- \\
13.20)\end{array}$ & 0.012 & $\begin{array}{c}8.40 \\
(7.00- \\
9.70)\end{array}$ & 0.012 & $\begin{array}{c}6.25 \\
(5.00- \\
7.40)\end{array}$ & 0.036 & $\begin{array}{c}5.90 \\
(5.00- \\
7.00)\end{array}$ & 0.030 & $\begin{array}{c}5.15 \\
(4.00- \\
6.20)\end{array}$ & 0.888 & $\begin{array}{c}4.65 \\
(4.00- \\
6.00)\end{array}$ & 0.292 \\
\hline 2 & $\begin{array}{c}3.65 \\
(2.75- \\
5.15)\end{array}$ & $\begin{array}{l}6.45 \\
(5.80- \\
10.30)\end{array}$ & 0.012 & $\begin{array}{r}7.20 \\
(6.00- \\
10.90)\end{array}$ & 0.012 & $\begin{array}{c}7.05 \\
(5.70- \\
9.70)\end{array}$ & 0.011 & $\begin{array}{l}4.75 \\
(4.00- \\
6.70)\end{array}$ & 0.012 & $\begin{array}{r}4.00 \\
(3.00- \\
5.00)\end{array}$ & 0.499 & $\begin{array}{c}3.70 \\
(3.00- \\
5.10)\end{array}$ & 0.361 & $\begin{array}{r}3.55 \\
(3.00- \\
4.90)\end{array}$ & 0.833 \\
\hline 3 & $\begin{array}{c}3.07 \\
(2.85- \\
3.90)\end{array}$ & $\begin{array}{c}6.95 \\
(6.20- \\
7.20)\end{array}$ & 0.012 & $\begin{array}{r}6.35 \\
(6.20 \\
8.00)\end{array}$ & 0.011 & $\begin{array}{l}6.45 \\
(6.00- \\
7.70)\end{array}$ & 0.012 & $\begin{array}{c}3.60 \\
(3.00- \\
5.10)\end{array}$ & 0.043 & $\begin{array}{r}3.15 \\
(3.00- \\
4.00)\end{array}$ & 0.400 & $\begin{array}{c}3.20 \\
(2.50- \\
3.50)\end{array}$ & 0.574 & $\begin{array}{c}2.85 \\
(2.50- \\
3.50)\end{array}$ & 0.093 \\
\hline 4 & $\begin{array}{c}3.47 \\
(3.10- \\
4.10)\end{array}$ & $\begin{array}{r}7.10 \\
(6.50- \\
8.10)\end{array}$ & 0.012 & $\begin{array}{c}7.20 \\
(6.70- \\
8.00)\end{array}$ & 0.012 & $\begin{array}{c}7.20 \\
(6.40- \\
8.20)\end{array}$ & 0.012 & $\begin{array}{c}5.15 \\
(4.60- \\
6.70)\end{array}$ & 0.012 & $\begin{array}{r}3.85 \\
(3.60- \\
5.00)\end{array}$ & 0.012 & $\begin{array}{l}3.25 \\
(3.00- \\
3.70)\end{array}$ & 0.068 & $\begin{array}{r}3.25 \\
(3.10- \\
3.70)\end{array}$ & 0.075 \\
\hline 5 & $\begin{array}{l}3.52 \\
(3.24 \\
3.75)\end{array}$ & $\begin{array}{l}7.65 \\
(7.20- \\
7.80)\end{array}$ & 0.012 & $\begin{array}{r}7.45 \\
(7.30- \\
7.90)\end{array}$ & 0.012 & $\begin{array}{r}7.25 \\
(6.90- \\
7.50)\end{array}$ & 0.012 & $\begin{array}{r}4.90 \\
(4.20- \\
5.20)\end{array}$ & 0.012 & $\begin{array}{l}4.10 \\
(4.00- \\
4.90)\end{array}$ & 0.012 & $\begin{array}{r}3.75 \\
(3.00- \\
4.30)\end{array}$ & 0.122 & $\begin{array}{r}3.45 \\
(3.10- \\
4.20)\end{array}$ & 0.574 \\
\hline
\end{tabular}


Similar rates of nonspecific changes such as edema and gliosis were seen in both groups. Signs of severe reactions such as neuronal degeneration and diffuse inflammatory cell infiltration were not encountered in any group (Figures 1-4). According to histopathological findings of both regions of the spinal cord, no significant intergroup difference was detected on the $6^{\text {th }}$ or the $21^{\text {st }}$ day $(p>0.05)($ Tables 3,4$)$.

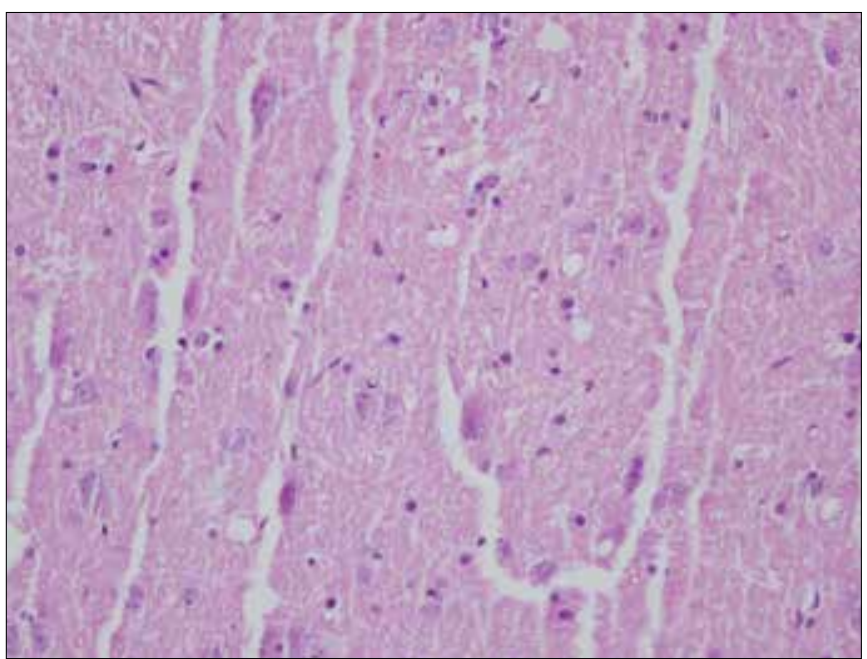

Figure 1. Histologic assessment of spinal cord in Group $D$ on the $6^{\text {th }}$ day (x400 magnification, Hematoxylin\&Eosin)

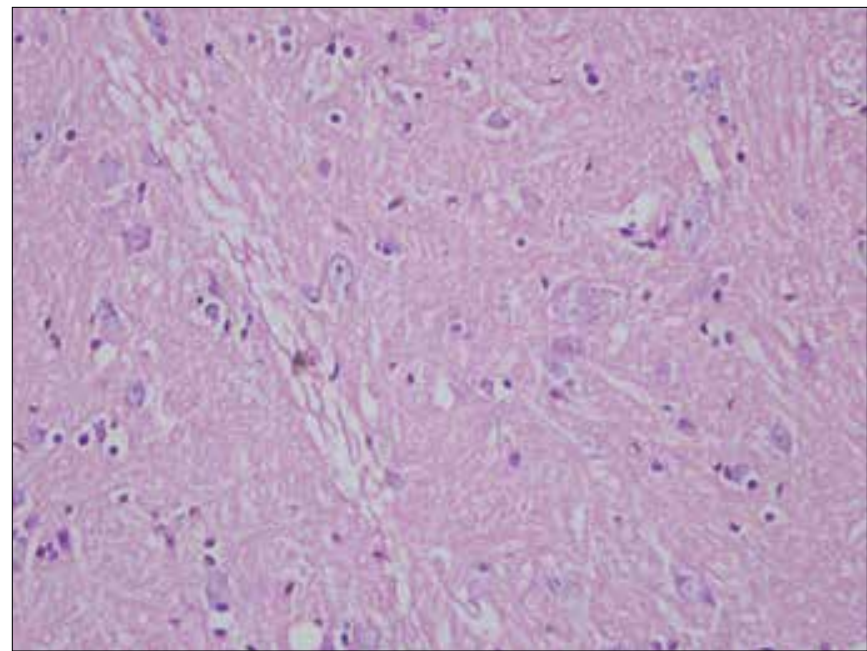

Figure 3. Histologic assessment of spinal cord sections in Group D on the $21^{\text {th }}$ day (x400 magnification, Hematoxylin\&Eosin)

\section{Discussion}

Compared with other alpha ${ }_{2}$ agonists, dexmedetomidine has a higher receptor specificity, selectivity, and potentially increased analgesic efficacy. Therefore, it can be an ideal adjuvant to local anaesthetics in neuroaxial blocks. The analgesic effect of dexmedetomidine has been investigated in many

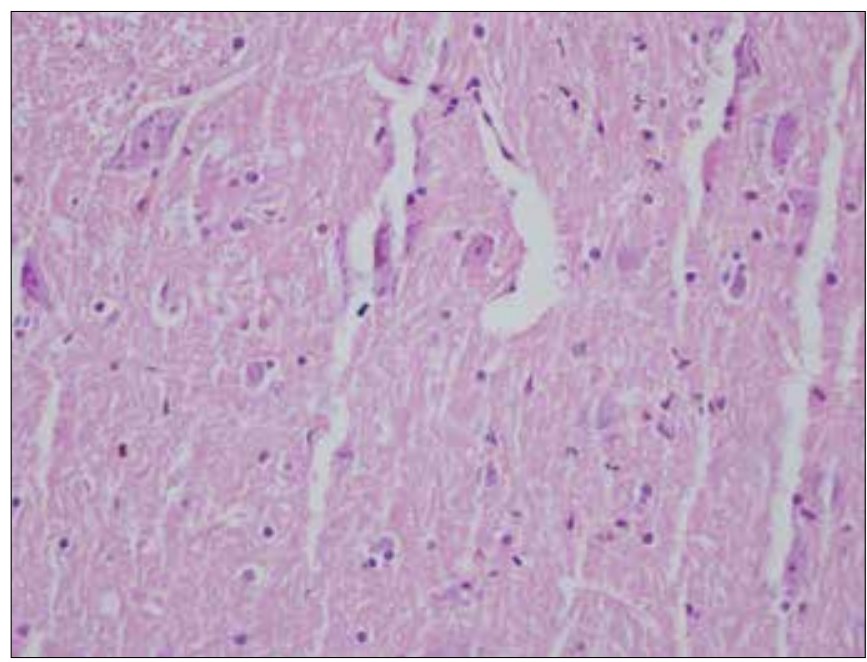

Figure 2. Histologic assessment of spinal cord in Group $C$ on the $6^{\text {th }}$ day(x400 magnification, Hematoxylin\&Eosin)

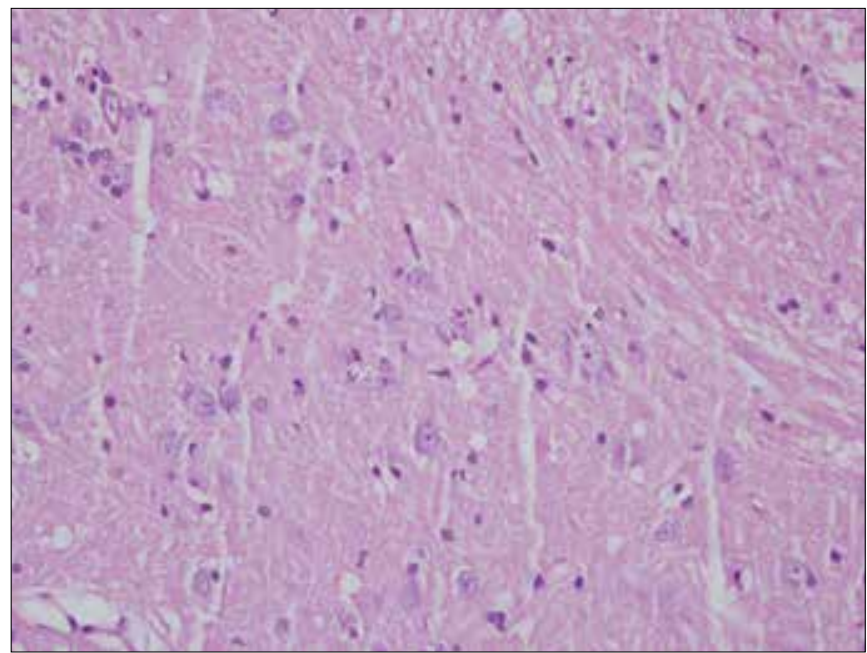

Figure 4. Histologic assessment of spinal cord in Group C on the $21^{\text {th }}$ day (x400 magnification, Hematoxylin\&Eosin)

Table 3. Histopathological evaluation of cervical spinal cord, number of rats (\%)

\begin{tabular}{|c|c|c|c|c|}
\hline \multirow[b]{2}{*}{ Changes } & \multicolumn{2}{|c|}{$6^{\text {th }}$ Day } & \multicolumn{2}{|c|}{$21^{\text {st }}$ Day } \\
\hline & Group D (n=8) & Group C (n=7) & Group $D(n=7)$ & Group $C(n=8)$ \\
\hline Nonspecific changes & $5(63 \%)$ & $6(86 \%)$ & $7(100 \%)$ & $5(63 \%)$ \\
\hline Mild changes & $3(37 \%)$ & $1(14 \%)$ & $0(0 \%)$ & $3(37 \%)$ \\
\hline Markedly severe changes & $0(0 \%)$ & $0(0 \%)$ & $0(0 \%)$ & $0(0 \%)$ \\
\hline$p$ & \multicolumn{2}{|c|}{0.119} & \multicolumn{2}{|c|}{0.200} \\
\hline
\end{tabular}


Table 4. Histopathological evaluation of lumbar spinal cord, number of rats (\%)

\begin{tabular}{|c|c|c|c|c|}
\hline \multirow[b]{2}{*}{ Changes } & \multicolumn{2}{|c|}{$6^{\text {th }}$ Day } & \multicolumn{2}{|c|}{$21^{\text {st }}$ Day } \\
\hline & Group $D(n=8)$ & Group C (n=7) & Group D $(n=7)$ & Group C ( $n=8)$ \\
\hline Nonspecific changes & $6(75 \%)$ & $6(86 \%)$ & $7(100 \%)$ & $8(100 \%)$ \\
\hline Mild changes & $2(25 \%)$ & $1(14 \%)$ & $0(0 \%)$ & $0(0 \%)$ \\
\hline Markedly severe changes & $0(0 \%)$ & $0(0 \%)$ & $0(0 \%)$ & $0(0 \%)$ \\
\hline$p$ & \multicolumn{2}{|c|}{1.000} & \multicolumn{2}{|c|}{ - } \\
\hline
\end{tabular}

studies. In these studies, the sedative and analgesic effectiveness of alpha ${ }_{2}$ agonists have been demonstrated $(16,17)$.

In previous studies, Fisher et al. (18) detected significantly prolonged latencies in hot plate and tail-flick tests in rats that received intrathecal dexmedetomidine at doses of 3 and $10 \mu \mathrm{g}$. Joo et al. (19) evaluated the analgesic effectiveness of intrathecal $0.3,1,3$, and $10 \mu \mathrm{g}$ dexmedetomidine in rats by means of the tail-flick test, and observed a dose-related effect that started at a dose of $3 \mu \mathrm{g}$. They also demonstrated sedationinduced effects with the same doses. Kalso et al. (20) delivered dexmedetomidine via the intrathecal route to rats at doses of $1.5,3$, and $6 \mu \mathrm{g}$, and evaluated its antinociceptive effectiveness using the tail-flick test. They detected the onset of antinociceptive effect at a dose of $3 \mu \mathrm{g}$. Kanazi et al. (21) added $3 \mu \mathrm{g}$ dexmedetomidine or $30 \mu \mathrm{g}$ clonidine to intrathecal 12 mg bupivacaine for patients undergoing transurethral resection of prostate or bladder tumour. They concluded that $3 \mu \mathrm{g}$ dexmedetomidine and $30 \mu \mathrm{g}$ clonidine prolonged sensory and motor block duration. Al-Mustafa et al. (22) added $5 \mu \mathrm{g}$ or $10 \mu \mathrm{g}$ dexmedetomidine to intrathecal $12.5 \mathrm{mg}$ bupivacaine for patients undergoing transurethral resection of prostate or bladder tumour, or placement of tension-free vaginal tape for urinary incontinence control. They concluded that dexmedetomidine reduced the onset and prolonged the duration of sensory and motor block. Mohamed et al. (23) found that addition of $5 \mu \mathrm{g}$ dexmedetomidine to $10 \mathrm{mg}$ bupivacaine intrathecally in patients before major abdominal cancer surgery improved the duration and quality of postoperative analgesia. In a previous study, Xiang et al. (24) added dexmedetomidine to bupivacaine in 60 children aged 1-6 years. Thirty children received 1 $\mathrm{mL} / \mathrm{kg}$ volume of $0.25 \%$ bupivacaine plus $1 \mu \mathrm{g} / \mathrm{kg}$ dexmedetomidine caudally. Other children received $1 \mathrm{~mL} / \mathrm{kg}$ of $0.25 \%$ bupivacaine. They concluded that addition of dexmedetomidine to bupivacaine caudally reduced the response to hernial sac traction and improved the duration of postoperative analgesia. In our study, we used the lowest effective analgesic dose of dexmedetomidine, $3 \mu \mathrm{g}$ (approximately $10 \mu \mathrm{g} / \mathrm{kg}$ ), and similarly detected that this dose-induced significant increase in latent periods, as evaluated by the tail-flick and hot plate tests. The reaction times at $90 \mathrm{~min}$ on the first day, at $60 \mathrm{~min}$ on the second day, at 40,60, and $90 \mathrm{~min}$ on the third day, and at $90 \mathrm{~min}$ on the fifth day in hot plate tests were shorter than baseline values. A shorter reaction time compared with baseline values depends on the learning phenomena of rats (25).

Although dexmedetomidine is not effective on the neuromuscular junction, it exerts a central effect on muscles, like ben- zodiazepines. It can provide muscular relaxation via central pathways without affecting the neuromuscular junction (26). Similarly, we observed the loss of stepping and righting reflexes in rats that received intrathecal dexmedetomidine. However, this effect might be related to decreased muscular tone secondary to sedation and the central effects of dexmedetomidine.

Dexmedetomidine exerts its anxiolytic and sedative effects via activation of alpha ${ }_{2}$ adrenoceptors in the locus coeruleus, which is the major adrenergic innervation area in the central nervous system. Dexmedetomidine can provide sedoanalgesia especially without inducing respiratory depression. It is a potent selective alpha ${ }_{2}$ agonist with sedative, analgesic, and anxiolytic properties (27). Burkle et al. (28) administered three different alpha adrenergic agonists to rats, i.e., dexmedetomidine, clonidine, and UK-14.304 via the intracerebroventricular route, at doses of 3-10 $\mu \mathrm{g}, 10-100 \mu \mathrm{g}$, and 3-30 $\mu \mathrm{g}$, and detected stronger sedative effects of dexmedetomidine compared with the other agonists. In our study, we also observed a prominent sedative effect with $3 \mu \mathrm{g}$ dexmedetomidine, which developed very rapidly and immediately after intracerebroventricular administration of the drug.

Drugs directly administered through the intrathecal route carry risks of central nervous system damage and neurotoxicity. Safe usage of intrathecally administered drugs requires unequivocal disclosure of their effects on the central nervous system. In rats that received only physiological saline injections through an intrathecal catheter, numerous mononuclear inflammatory cells in the regions adjacent to the leptomeninx along the course of the catheter were seen, while inflammatory cell infiltration occurred less frequently in rats that were only catheterised (29). Therefore, we preferred to use the intracerebroventricular catheterisation technique, which has no direct contact with the spinal cord in order to prevent the occurrence of potential histopathological adverse effects (fibrosis and lymphocytic infiltration) secondary to the implantation of an intrathecal catheter.

This study has several limitations. We administered dexmedetomidine intracerebroventricularly; furthermore, it was not shown that dexmedetomidine reached the spinal area, and no samples were obtained from the locus coeruleus for histopathological evaluation. Thus, although neurotoxicity was not observed in the spinal cord it does not mean that it was not present in other parts of the nervous system and ventricular system.

In previous studies, with intrathecal administration of higher doses of the alpha ${ }_{2}$ agonist clonidine, no neurotoxic 
effects on the spinal cord or nerve roots were encountered $(29,30)$. Konakcl et al. (31) revealed demyelination of oligodendrocytes in the white matter of the spinal cord after epidural administration of 5 and $10 \mu \mathrm{g}$ dexmedetomidine. Although histopathological evaluation was performed immediately after administration of dexmedetomidine and 1 day following epidural catheterisation, this study lacked a saline control group. Tachibana et al. (32) administered dexmedetomidine at doses of 5 and $10 \mu \mathrm{g} / \mathrm{kg}$ i.p. in rat pups to clarify the long-term neurological results. They demonstrated that these doses were enough for long-term elevation of plasma dexmedetomidine concentration. Their findings suggest that dexmedetomidine at doses of 5 and $10 \mu \mathrm{g} / \mathrm{kg}$ does not impair hippocampal synaptic activity after maturation. Gul et al. (33) evaluated the neuroprotective effects of dexmedetomidine in a rat spinal cord injury model. Their findings suggest that i.p. $10 \mu \mathrm{g} / \mathrm{kg}$ dexmedetomidine may have a neuroprotective effect by inhibition of lipid peroxidation in spinal cord injury. Zhu et al. (34) found that intravenous administration of $15 \mu \mathrm{g} /$ $\mathrm{kg}$ dexmedetomidine protected the brain against focal cerebral ischaemia/reperfusion in rats after middle cerebral artery occlusion. They concluded that dexmedetomidine decreased the neurological deficit score, brain edema, cerebral infarct volume, and neuronal death. Brummet et al. (35) added dexmedetomidine to bupivacaine for sciatic nerve block in rats to evaluate its neurotoxic effect. In their study, they used higher doses $(28-40 \mu \mathrm{g} / \mathrm{kg})$ of dexmedetomidine. They performed histopathological evaluations at 24 hours, and 14 days later and demonstrated that all of the nerves had normal axons and myelin. In the present study, we also did not encounter any finding to suggest the neurotoxicity of dexmedetomidine.

In conclusion, intracerebroventricular administration of $3 \mu \mathrm{g}$ dexmedetomidine in rats induces antinociceptive and sedative effects without any neurotoxic impact on the spinal cord.

Ethics Committee Approval: Ethics committee approval was received for this study (22.01.2008-OMU-HADYEK/08).

\section{Informed Consent: N/A}

Peer-review: Externally peer-reviewed.

Author contributions: Concept - E.K., D.K., B.C., A.B.; Design - E.K., D.K., B.C., A.B.; Supervision - E.K., S.B., S.S.B.,Y.B.U.; Resource - E.K., D.K., B.C., A.B., S.B., S.S.B., Y.B.U.; Materials - E.K., D.K., B.C., A.B., S.B., S.S.B., Y.B.U; Data Collection\&/or Processing - E.K., B.C.,Y.B.U.; Analysis\&/or Interpretation - E.K., D.K.; Literature Search - E.K., D.K., B.C, A.B., Y.B.U.; Writing - E.K., D.K., B.C., A.B., S.B., S.S.B., Y.B.U; Critical Reviews - E.K., D.K., B.C., A.B.

Conflict of Interest: No conflict of interest was declared by the authors.

Financial Disclosure: The authors declared that this study received no financial support.

\section{References}

1. Jones SL, Gebhart GF. Characterization of coeruleospinal inhibition of the nociceptive tail-flick reflex in the rat: mediation by spinal alpha 2-adrenoceptors. Brain Res 1986;364:315-30. [CrossRef]

2. D'Angelo R. Should we administer epidural or spinal clonidine during labor? Reg Anesth Pain Med 2000;25:3-4. [CrossRef]
3. Mercier FJ, Boulay G, Ber Ayed M, Benhamou D. Combined spinal and epidural analgesia for labor. Prolongation by the addition of a minidose of clonidine to sufentanil. An initial study. Ann Fr Anesth Reanim 1996;15:263-5. [CrossRef]

4. Khan ZP, Ferguson CN, Jones RM. Alpha-2 and imidazoline receptor agonists. Their pharmacology and therapeutic role. Anaesthesia 1999;54:146-165. [CrossRef]

5. Lakhlani PP, MacMillan LB, Guo TZ. Substitution of a mutant alpha2 adrenergic receptor via "hit and run" gene targeting reveals the role of this subtype in sedative, analgesic, and anesthetic-sparing responses in vivo. Proc Natl Acad Sci 1997;94:9950-5. [CrossRef]

6. Yaksh TL. Pharmacology of spinal noradrenergic systems which modulate spinal nociceptive processing. Pharmacol Biochem Behav 1985;22:845-58. [CrossRef]

7. Stevens CW, Brenner GM. Spinal administration of adrenergic agents produces analgesia in amphibians. Eur $\mathrm{J}$ Pharmacol 1996;316:205-10. [CrossRef]

8. Loo CC, Dahlgren G, Irestedt L. Neurological complications in obstetric regional anaesthesia. Int J Obstet Anesth 2000;9:99124. [CrossRef]

9. Horlocker TT, Wedel DJ. Neurologic complications of spinal and epidural anesthesia. Reg Anesth Pain Med 2000;25:83-98. [CrossRef]

10. Paxinos G, Watson C: The Rat Brain in Stereotaxic Coordinates, 4th edition. San Diego, Academic Press, 1998, pp 19-66.

11. Eddy Nb, Leimbach D. Synthetic Analgesics. II. Dithienylbutenyl and Dithienylbutylamines. J Pharmacol Exp Ther 1953;107:385-93.

12. D'Amour FE, Smith DL. A method for determining loss of pain sensation. J Pharmacol Exp Ther 1941;72:74-79.

13. Archer DP, Lamberty $Y$, Wang B, Davis MJ, Samanani N, Roth SH. Levetiracetam reduces anesthetic-induced hyperalgesia in rats. Anesth Analg 2007;104:180-5.[CrossRef]

14. Yamamoto T, Nozaki-Taguchi N, Chiba T. Analgesic effect of intrathecally administered orexin- $A$ in the rat formalin test and in the rat hot plate test. Br J Pharmacol 2002;137:170-6. [CrossRef]

15. Koizumi Y, Matsumoto M, Yamashita A, Tsuruta S, Ohtake T, Sakabe T. The effects of an AMPA receptor antagonist on the neurotoxicity of tetracaine intrathecally administered in rabbits. Anesth Analg 2006;102:930-6. [CrossRef]

16. Maze $M$, Tranquilli W. Alpha-2 adrenoceptor agonists: Defining the role in clinical anesthesia. Anesthesiology 1991;74:581-605. [CrossRef]

17. Eisenach JC, De Kock M, Klimscha W. Alpha2 adrenergic agonists for regional anesthesia: a clinical review of clonidine (19841995). Anesthesiology 1996;85:655-74. [CrossRef]

18. Fisher B, Zornow MH, Yaksh TL, Peterson BM. Antinociceptive properties of intrathecal dexmedetomidine in rats. Eur J Pharmacol 1991;192:221-5. [CrossRef]

19. Joo G, Horvath G, Klimscha W, Kekesi G, Dobos I, Szikszay M, et al. The effects of ketamine and its enantiomers on the morphine or dexmedetomidine-induced antinociception after intrathecal administration in rats. Anesthesiology 2000;93:231-41. [CrossRef]

20. Kalso EA, Pöyhia R, Rosenberg PH. Spinal antinociception by dexmedetomidine, a highyl selective $\alpha 2$-adrenergic agonist. Pharmacol Toxicol 1991;68:140-3. [CrossRef]

21. Kanazi GE, Aouad MT, Jabbour-Khoury SI, Al Jazzar MD, Alameddine MM, Al-Yaman R, et al. Effect of low dose dexmedetomidine or clonidine on the characteristics of bupivacaine spinal block. Acta Anaesthesiol Scand 2006;50:222-7. [CrossRef]

22. Al-Mustafa MM, Abu-Halaweh SA, Aloweidi AS, Murshidi MM, Ammari BA, Awwad ZM, et al. Effect of dexmedetomidine added to spinal bupivacaine for urological procedures. Saudi Med J 2009;30:365-70. 
23. Mohamed AA, Fares KM, Mohamed SA. Efficacy of intrathecally administered dexmedetomidine versus dexmedetomidine with fentanyl in patients undergoing major abdominal cancer surgery. Pain Physician 2012;15:339-48.

24. Xiang $Q$, Huang DY, Zhao YL, Wang GH, Liu YX, Zhong L, et al. Caudal dexmedetomidine combined with bupivacaine inhibit the response to hernia sac traction in children undergoing inguinal hernia repair. Br J Anaesth 2013;110:420-4. [CrossRef]

25. Espejo EF, Mir D. Structure of the rat's behaviour in the hot plate test. Behav Brain Res 1993;56:171-6. [CrossRef]

26. Talke PO, Caldwell JE, Richardson CA, Kirkegaard-Nielsen $H$, Stafford $M$. The effects of dexmedetomidine on neuromuscular blockade in human volunteers. Anesth Analg 1999;88:633-9. [CrossRef]

27. Venn RM, Karol MD, Grounds RM. Pharmacokinetics of dexmedetomidine infusions for sedation of postoperative patients requiring intensive car. Br J Anaesth 2002;88:669-75. [CrossRef]

28. Buerkle H, Yaksh TL. Pharmacological evidence for different alpha 2-adrenergic receptor sites mediating analgesia and sedation in the rat. Br J Anaesth 1998;81:208-15. [CrossRef]

29. Gordh T Jr, Post C, Olsson Y. Evaluation of the toxicity of subarachnoid clonidine, guanfacine and substance $p$-antagonist on rat spinal cord and nerve roots:Light and electron microscopic observations after chronic intrathecal administration. Anesth Analg 1986;65:1303-11. [CrossRef]

30. Gordh TE, Ekman S, Lagerstedt AS. Evaluation of possible spinal neurotoxicity of clonidine. Ups J Med Sci 1984;89:266-73. [CrossRef]

31. Konakci S, Adanir T, Yilmaz G, Rezanko T. The efficacy and neurotoxicity of dexmedetomidine administered via the epidural route. Eur J Anaesthesiol 2008;25:403-9. [CrossRef]

32. Tachibana K, Hashimoto $T$, Kato R, Uchida Y, Ito R, Takita K, et al. Neonatal administration with dexmedetomidine does not impair the rat hippocampal synaptic plasticity later in adulthood. Paediatr Anaesth 2012;22:713-9. [CrossRef]

33. Gul S, Hanci V, Bahadir B, Acikgoz S, Bektas S, Ankarali H, et al.The effectiveness of dexmedetomidine in experimental spinal cord injury compared to methylprednisolone in rats. J Clin Neurosci 2010;17:490-4. [CrossRef]

34. Zhu YM, Wang CC, Chen L, Qian LB, Ma LL, Yu J, et al. Both $\mathrm{PI} 3 \mathrm{~K} / \mathrm{Akt}$ and ERK1/2 pathways participate in the protection by dexmedetomidine against transient focalcerebral ischemia/reperfusion injury in rats. Brain Res 2013;1494:1-8. [CrossRef]

35. Brummett CM, Norat MA, Palmisano JM, Lydic R. Perineural administration of dexmedetomidine in combination with bupivacaine enhances sensory and motor blockade in sciatic nerve block without inducing neurotoxicity in rat. Anesthesiology 2008;109:502-11. [CrossRef] 